\title{
Penguasaan Hak Asuh Anak di bawah Umur kepada Bapak
}

Fawzia Hidayatul Ulya, Fashi Hatul Lisaniyah, Mu'amaroh

UIN Walisongo Semarang, Institut Agama Islam Nahdlatul Ulama Tuban

Email: fawziaulya645@gmail.com, lisaniyah1@gmail.com, muamaroh281@gmail.com

\begin{abstract}
Abstrak: Hadhanah adalah persoalan pemeliharaan anak/hak asuh anak. Didalam KHI Pasal 105 hufuf a menyatakan bahwa pemeliharaan anak yang belum mumayyiz atau belum berumur 12 tahun adalah hak ibunya. Kemudian didalam Pasal 156 KHI juga dijelaskan bahwa, apabila ibu meninggal dunia atau tidak memenuhi persyaratan sebagai pengasuh, maka sesuai urutan akan dikuasakan kepada garis keturunan ibu. Tetapi dalam beberapa kasus salah satunya di dalam putusan No 0830/Pdt.G/2019/PA.Dmk mengabulkan permohonan pemohon dengan menetapkan hak asuh anak dibawah umur kepada bapak, yang dalam ini berkedudukan sebagai pemohon. Jenis penelitian ini menggunakan jenis penelitian normatif, analisis data dengan menggunakan metode deskriptif analisis. Kesimpulan yang dapat dijelaskan dalam penelitian ini, adalah; Pasal 105 Kompilasi Hukum Islam bahwa hak asuh anak yang masih berusia dibawah 12 tahun adalah hak ibunya, tetapi ada beberapa peraturan perundang-undangan di Indonesia yang dapat dijadikan acuan agar hak asuh anak di bawah umur tersebut dapat dikuasakan kepada bapak kandungnya, diantaranya Pasal 41 Undang-Undang Nomor 1 Tahun 1974 tentang Perkawinan, Pasal 49 Undang-Undang Perkawinan mengenai permintaan pencabutan hak asuh anak oleh salah satu ataupun kedua orang tua maupun keluarga dari anak tersebut dan Pasal 14 Undang-Undang Perlindungan Anak mengenai pemisahan seorang anak dengan salah satu atau kedua orang tua.
\end{abstract}

Kata Kunci: Hadhanah, mumayyiz, bapak.

\section{Pendahuluan}

Perkawinan sebagai pengejawantahan dari reunifikasi kemanusiaan. Hal ini berarti laki-laki dan perempuan mempunyai kepentingan yang sama atas perkawinan mereka, dan oleh karena itu didalam perkawinan seharusnya tidak diperhitungkan lagi antara kepentingan laki-laki pada satu fihak dan kepentingan perempuan pada fihak lain secara dominan apalagi subordinat oleh salah satu fihak. Suami isteri mempunyai satu 
kepentingan yang sama dalam perkawinan, satu dengan yang lain masing-masing sebagai unsur perekat dan penyatu dalam rumah tangga, satu dengan lainnya tidak ada subordinasi, perbedaan, apalagi kepentingan mutlak. Konsep perkawinan seharusnya difahami sebagai pernghargaan atas harkat dan martabat kemanusiaan.Isteri milik suami demikian juga suami milik istri masing-masing saling memiliki dan saling menyayangi. ${ }^{1}$

Dalam rumah tangga, meskipun pada awalnya hanya ada dua individu saja yakni suami dan istri, menjalin sebuah hubungan penuh dengan kasih sayang seolah-olah akan berjalan sesuai alur dan bertahan seiring berjalannya waktu. Namun pada kenyataannya dengan adanya perbedaan dan kasih sayang yang tidak dirawat secara selaras dengan rasa saling mengayomi dan menghargai akan pudar, bahkan akan berubah menjadi rasa kebencian yang amat besar. Jika sebuah pertentangan di dalam keluarga muncul antara suami dan istri yang tentunya tidak mendapat jalan pemecahan dan tidak berangsur membaik seperti keadaan semula. Keadaan tersebut tentu tidak akan berdampak baik pada kondisi fisik dan psikis anaknya. ${ }^{2}$

Suatu gugatan perceraian ini akhirnya menimbulkan berbagai permasalahan. Di samping gugatan cerai itu menimbulkan putusnya suatu ikatan perkawinan, Muncul pula masalah setelah dikabulkannya gugatan perceraian itu misalnya, perebutan harta gono gini, dan apabila sudah memiliki keturunan timbul masalah pula masalah tentang siapa yang lebih berhak mengasuh atau mendapatkan hak asuh anak yang masih dibawah umur. Kemudian masalah yang paling pokok dalam pemeliharaan anak adalah syarat-syarat yang menjadi Hadhin, karena sifat seorang pengasuh akan berpengaruh kuat terhadap anak yang menjadi asuhannya, keberhasilan anak dalam perkembangan, kedewasaan, dan pendidikannya. Sebab ciri dasar manusia adalah bersifat dinamis, merdeka, dan sosial. Maka pada saat inilah seorang anak diberikan pendidikan yang paling besar sifatnya seperti diajarinya seorang anak mengenal Tuhan sebagai bekal tauhid dan jiwanya.

Bilamana terjadi perceraian, maka orang yang paling berhak

\footnotetext{
${ }^{1}$ Ali Imron, Memahami Konsep Perceraian Dalam Hukum Keluarga, (Buana GenderVol. I Nomor I, Januari - Juni 2016), hlm. 18.

2 Satria effendi M.Zeim, Problematika Hukum Keluarga Islam Hukum Keluarga Islam Kontemporer, (Jakarta: Kencana, 2004), hlm. 137.
} 
mengasuh dan memelihara anak-anaknya adalah ibunya. Apalagi anak dibawah usia 12 tahun masih sangat membutuhkan kasih sayang yang lebih. Ibu yang dianggap mampu pengatur pengoptimalan tumbuh kembang secara terpelihara. Meskipun secara fisik seorang laki-laki jauh lebih kuat dibandingkan perempuan, namun pada beberapa hal ibu jauh memiliki kemampuan yang tidak dimiliki oleh seorang suami. Jadi, peran ibu mendidik anaknya yang notabenya masih dibawah umur tidak bisa di gantikan oleh orang lain atau bahkan oleh suaminya sendiri. ${ }^{3}$

Secara istilah hadhanah adalah pendidikan dan pemeliharaan anak sejak dari lahir sampai sanggup berdiri sendiri mengurus dirinya yang dilakukan oleh kerabat anak itu. Menurut Sayyid Sabiq Hadhanah adalah melakukan pemeliharaan anak-anak yang masih kecil baik laki-laki atau perempuan atau yang sudah besar tapi belum tamziz, tanpa perintah dari padanya, menyediakan sesuatu yang menjadi kebaikannya, menjaganya dari suatu yang merusak jasmani, rohani, dan akalnya agar mampu berdiri sendiri dalam menghadapi hidup ${ }^{4}$ dan dapat memikul tanggung jawab apabila dia sudah dewasa.

Hadhanah dalam hukum perdata bisa disebut dengan istilah pengasuhan atau perwalian. Hak pengasuhan atau perwalian merupakan hak seorang anak dari orang tua dan juga merupakan kewajiban orang tua terhadap anak.

Ketentuan hadhanah akibat terjadi perceraian orang tuanya di atur dalam Kompilasi Hukum Islam dalam Pasal $105^{5}$ yaitu:

a. Pemeliharaan anak yang belum mumayyiz atau berumur 12 tahun adalah hak ibunya.

b. Pemeliharaan anak yang sudah mumayyiz diserahkan kepada anak untuk memilih ayah atau ibu sebagai pemegang hak pemeliharaannya.

c. Biaya pemeliharaan ditanggung oleh ayahnya.

Dalam kompilasi hukum Islam Pasal $156^{6}$ yang mengatur tentang hak hadhanah akibat perceraian yaitu:

\footnotetext{
3 Al-Hamdani, RisalahNikah: Hukum Perkawinan Islam, (Jakarta: Pustaka Amani, 2002). hlm.318.

${ }^{4}$ Zakiah Darajat, Ilmu Fiqh, (Yogyakarta: Dana Bakti Wakaf,1995) , hlm. 425.

${ }^{5}$ Pasal 105, KHI

${ }^{6}$ Pasal 156, KHI
} 
1. Anak yang belum mumayyiz berhak mendapatkan hadhanah dari ibunya, kecuali bila ibunya telah meninggal dunia, maka kedudukannya digantikan oleh:
a. Wanita-wanita dari garis keturunan ibu.
b. Ayah.
c. Wanita-wanita dari garis keturunan ayah.
d. Saudara perempuan dari anak yang bersangkutan.
e. Wanita-wanita kerabat sedarah menurut garis kesamping dari ayah.

2. Anak yang sudah mumayyiz berhak memilih untuk mendapatkan hadhanah dari ayah atau ibunya.

3. Apabila pemegang hadhanah tidak dapat menjamin keselamatan jasmani dan rohani anak, meskipun biaya nafkah dan hadhanah telah tercukupi, maka atas permintaan kerabat yang bersangkutan, Pengadilan Agama dapat memindahkan hak hadhanah pada kerabat lain yang mempunyai hak hadhanah pula. ${ }^{7}$

Apabila seorang suami menceraikan istri sedangkan ia memiliki seorang anak darinya, maka sang istri lebih berhak untuk memelihara anak tersebut sampai ia baligh dan selama ia tidak menikah dengan lakilaki lain. Menurut riwayat Imam Malik dalam kitab Muwaththa' dari Yahya bin Sa'id berkata Qasim bin Muhammad bahwa Umar bin Khatab mempunyai seorang anak, namanya 'Ashim bin Umar, kemudian ia bercerai, pada suatu waktu Umar pergi ke Quba dan menemui anaknya itu sedang bermain-main diatas kudanya. Dalam pada itu datanglah nenek si anak. Umar berkata: "anakku" wanita itu berkata pula "anakku".

Peran seorang ibu dalam mendidik anak tidak bisa di sejajarkan dengan bapak oleh karena itu, ibu memiliki naluri yang kuat terhadap anaknya dibandingkan bapaknya. Untuk itu, ibu memiliki keutamaankeutamaan dibandingkan bapak. Keutamaan-keutamaan tersebut adalah sebagai berikut:

a) Ibu lebih sabar dibandingkan bapak dalam hal mendidik anak.

b) Ibu memiliki insting alami yang tidak dimiliki oleh bapak.

c) Ibu lebih tahu karakter moral anak dibandingkan bapak.

Begitu besarnya peran ibu dalam mendidik anak sangat perlu diapresiasi. Mengingat ibu mempunyai peran ganda, peran sebagai

7 Undang-Undang Republik Indonesia Nomor 1 Tahun 1974 Tentang Perkawinan dan KHI, (Grahamedia Press), hlm.377. 
istri dan peran sebagai seorang ibu. Sebagai istri ia harus senantiasa taat kepada suaminya selagi suaminya tidak menjerumuskan kearah kemaksiatan dan kejahatan sedangkan ibu adalah penyelamat generasi yang masa depan dengan mendidik anak-anak kearah yang lebih baik.

\section{Metode Penelitian}

Jenis penelitian yang digunakan dalam penelitian ini termasuk penelitian hukum normatif yaitu dengan meneliti bahan pustaka atau data sekunder. Kepustakaan dilakukan dengan menggunakan buku-buku, kitab-kitab fiqih, perundang-undangan, dan yurisprudensi yang berhubungan dengan penelitian ini. Pendekatan penelitian yang digunakan adalah model pendekatan kasus, yaitu mempelajari normanorma atau kaidah hukum yang dilakukan dalam praktik hukum terutama mengenai kasus-kasus yang telah diputus oleh pengadilan.

\section{Konsep Hadhanah dalam Islam}

Hadhanah menurut bahasa berarti "meletakkan sesuatu dekat tulang rusuk atau di pangkuan". Karena ibu waktu menyusukan anaknya meletakkan dipangkuannya, seakan akan ibu disaat itu melindungi dan memelihara anaknya, sehingga "hadhanah" dijadikan istilah yang maksudnya: pendidikan dan pemeliharaan anak sampai sanggup berdiri sendiri mengurus dirinya yang dilakukan oleh kerabat anak itu. ${ }^{8}$ Para ulama' fiqih mendefinisikan hadhanah, yaitu melakukan pemeliharaan anak-anak yang masih kecil, baik laki-laki ataupun perempuan, atau yang sudah besar tetapi belum mumayyiz, menyediakan sesuatu yang menjadikan kebaikannya, menjaganya dari sesuatu yang menyakiti dan merusaknya, mendidik jasmani, rohani, dan akalnya agar mampu berdiri sendiri menghadapi hidup dan memikul tanggung jawabnya. ${ }^{9}$

Dalam buku perdata Islam di Indonesia, dikatakan bahwa hadhanah adalah memelihara seorang anak yang belum mampu hidup mandiri yang meliputi pendidikan dan segala sesuatu yang diperlukaannya baik dalam bentuk melaksanakan maupun dalam bentuk sesuatu yang dapat merusaknya. ${ }^{10}$ Sedangkan menurut KHI yang terdapat dalam Pasal 1 huruf $G$ dikatakan bahwa hadhanah atau memelihara anak adalah

8 Abdul Rahman Ghazaly, "Fikih Munakahat”.(Jakarta: Kencana, 2006) hlm. 175.

${ }^{9}$ Aminuddin \& Slamet Abidin, "Fikih Munakahat 2", (Bandung: Cv. Pustaka Setia, 1999), hlm 171.

10 Zainudin Ali, Hukum Perdata Islam di Indonesia, (Jakarta: Sinar Grafindo, 2016) hlm.67. 
kegiatan mengasuh, memelihara, dan mendidik anak hingga dewasa atau berdiri sendiri. ${ }^{11}$

Hukum hadhanah adalah wajib karena anak yang tidak diperlihara akan terancam keselamatannya. Karena itu, hadhanah hukumnya wajib sebagaimana pemberian nafkah kepadanya. Adapun dasar hukum tentang kewajiban orang tua dalam memelihara seorang anak sesuai dengan firman Allah pada Surat Al-Baqarah Ayat 233 yang artinya;

"Para ibu hendaklah menyusukan anak-anaknya selama dua tahun penuh, yaitu bagi yang ingin menyempurnakan penyusuan. dan kewajiban ayah memberi makan dan pakaian kepada para ibu dengan cara ma'ruf. seseorang tidak dibebani melainkan menurut kadar kesanggupannya. janganlah seorang ibu menderita kesengsaraan karena anaknya dan seorang ayah karena anaknya, dan warispun berkewajiban demikian. apabila keduanya ingin menyapih (sebelum dua tahun) dengan kerelaan keduanya dan permusyawaratan, maka tidak ada dosa atas keduanya. Dan jika kamu ingin anakmu disusukan oleh orang lain, maka tidak ada dosa bagimu apabila kamu memberikan pembayaran menurut yang patut. bertakwalah kamu kepada Allah dan ketahuilah bahwa Allah Maha melihat apa yang kamu kerjakan".

Dari ayat diatas dapat dipahami bahwa hadhanah adalah salah satu kewajiban bagi kedua orang tua yang mendapatkan hal tersebut, pengabaian terhadap anak adalah suatu penganiayaanterhadap anak tersebut. Pendidikan anak juga merupakan salah satu faktor yang amat penting dalam kehidupan keluarga. Orang tua berkewajiban untuk mengarahkan anak-anak mereka menjadi orang-orang yang beriman dan berakhlak mulia, serta patuh dalam melaksanakan ajaran agama dengan baik agar terhindar dari perbuatan dosa dan maksiat.

Masalah yang paling pokok dalam pemeliharaan anak adalah syaratsyarat orang yang menjadi Hadhin. Jika syarat-syarat tertentu tidak terpenuhi satu saja maka gugurlah kebolehan menyelenggarakan hadhanahnya.

Demi kepentingan masa depan anak serta pemeliharaannya diperlukan beberapa syarat bagi yang melakukan hadhanah, sebagai berikut:

1. Yang melakukan hadhanah hendaklah sudah baligh, berakal, tidak terganggu ingatannya, sebab hadhanah ini merupakan pekerjaan yang

11 Zainudin Ali, hlm.67. 
penuh dengan tanggung jawab. Oleh sebab itu, seorang ibu yang mendapat gangguan ingatan tidak layak melakukan tugas hadhanah. Ahmad bin Hambal menambahkan agar yang melakukan hadhanah tidak mengidap penyakit menular.

2. Mempunyai kemampuan dan kemauan untuk memelihara dan mendidik mahdun (anak yang diasuh), dan tidak terikat dengan suatu pekerjaan yang bisa mengakibatkan tugas hadhanah menjadi terlantar.

3. Seorang yang melakukan hadhanah hendaklah dapat dipercaya memegang amanah, sehingga dengan itu dapat lebih menjamin pemeliharaan anak. Orang yang rusak akhlaknya tidak dapat memberikan contoh yang baik kepada anak yang diasuh, oleh karena itu ia tidak layak melakukan tugas ini.

4. Jika yang akan melakukan hadhanah itu ibu kandung dari anak yang akan diasuh, disyaratkan tidak kawin dengan lelaki lain. Dasarnya adalah penjelasan Rasulullah bahwa seorang ibu hanya mempunyai hak hadhanah bagi anaknya selama ia belum menikah dengan lelaki lain (HR. Abu Daud). Adanya persyaratan tersebut disebabkan kekhawatiran suami kedua tidak merelakan istrinya disibukkan mengurus anaknya dari suami pertama. Oleh karena itu, seperti disimpulkan ahli-ahli fiqh, hak hadhanahnya tidak menjadi gugur jika ia menikah dengan kerabat dekat si anak, yang memperlihatkan kasih sayang dan tanggung jawabnya. Demikian pula hak hadhanah, hak hadhanah tidak gugur jika ia menikah dengan lelaki lain yang rela menerima kenyataan.

5. Seorang yang melakukan hadhanah harus beragama Islam. Orang kafir tidak boleh menjadi pengasuh anak yang beragama Islam.

\section{Hadhanah dalam Undang-Undang Nomor 1 Tahun 1974}

Dalam Undang-Undang Nomor 1 Tahun 1974 Tentang Perkawinan telah disebutkan tentang hukum penguasaan anak secara tegas merupakan rangkaian dari hukum perkawinan di Indonesia. Dalam Undang-undang Nomor 1 Tahun 1974 terdapat beberapa pasal yang menjelaskan hak dan kewajiban antara orang tua dan anak seperti pada Pasal 45 Undang-Undang nomor 1 Tahun 1974 Tentang Perkawinan menyebutkan bahwa:

1) Kedua orang tua memiliki kewajiban memelihara dan mendidik anakanak mereka sebaik-baiknya. 
2) Kewajiban tersebut berlaku sampai anak itu menikah atau dapat berdiri sendiri dan kewajiban tersebut berlaku terus meskipun pernikahan antara kedua orang tua putus. ${ }^{12}$

Mengenai batas kewajiban pemeliharaan dan pendidikan ini berlaku sampai anak tersebut berumah tangga atau dapat berdiri sendiri dan kewajiban tersebut berlangsung terus-menerus meskipun pernikahan orang tuanya bercerai.

Pasal 47 Undang-Undang Nomor 1 Tahun 1974 Tentang Perkawinan mengatur mengenai kekuasaan orang tua terhadap kekuasaan anak di bawah umur, di mana disebutkan bahwa:

\section{Pasal $46^{13}$}

1) Anak wajib menghormati orang tua dan mentaati kehendak mereka yang baik.

2) Jika anak yang telah dewasa, ia wajib memelihara menurut kemampuanya, orang tua dan keluarga dalam garis lurus ke atas bila mereka itu memerlukan bantuanya.

\section{Pasal 4714}

1) Anak yang belum mencapai umur 18 (depan belas) tahun atau yang belum pernah melangsungkan pernikahan ada di bawah kekuasaan orang tuanya selama mereka tidak dicabut dari kekuasaanya.

2) Orang tua mewakili anak tersebut mengenai segala perbuatan hukum di dalam dan di luar Pengadilan.

\section{Pasal $48^{15}$}

Orang tua tidak diperbolehkan memindahkan hak atau menggadaikan barang-barang tetap yang dimiliki anaknya yang belum berumur 18 (delapan belas) tahun atau belum pernah melangsungkan perkawinan, kecuali apabila kepentingan anak itu menghendakinya.

\section{Pasal 4916}

1) Salah seorang atau kedua orang tua dapat dicabut kekuasaannya terhadap seorang anak atau lebih untuk waktu tertentu atas permintaan orang tua yang lain, keluarga anak dalam garis lurus keatas dan saudara kandung yang telah dewasa atau pejabat yang berwenang, dengan keputusan Pengadilan dalam hal-hal:

a. Ia sangat melalaikan kewajibannya terhadap anaknya.

b. Ia berkelakuan buruk sekali.

\footnotetext{
12Pasal 45 Undang-Undang Nomor 1 tahun 1974 Tentang Perkawinan

${ }_{13}$ Pasal 46 Undang-Undang Nomor 1 tahun 1974 Tentang Perkawinan

14 Pasal 47 Undang-Undang Nomor 1 tahun 1974 Tentang Perkawinan

15 Pasal 48 Undang-Undang Nomor 1 tahun 1974 Tentang Perkawinan

16 Pasal 49 Undang-Undang Nomor 1 tahun 1974 Tentang Perkawinan
} 
c. Meskipun orang tua dicabut kekuasaannya, mereka masih berkewajiban untuk memberi biaya pemeliharaan kepada anak tersebut.

Ketentuan tersebut pun tetap berlaku meskipun pernikahan orang tuanya putus. Jadi dalam Undang-Undang Nomor 1 Tahun 1974 Tentang perkawinan, kekuasan orang tua itu dapat dicabut jika orang tuanya sangat melalaikan kewajibannya terhadap anaknya dan salah satu orang tuanya berkelakuan buruk sekali. Tetapi meskipun kekuasaannya dicabut mereka masih berkewajiban memberi pemeliharaan dan mengasuh anaknya tersebut.

\section{Kompilasi Hukum Islam (KHI)}

Dalam Kompilasi Hukum Islam (KHI) masalah pemeliharaan anak atau yang dalam Islam disebut hadhanah diatur dalam beberapa pasal didalamnya, seperti yang terdapat dalam pasal:

\section{Pasal $105^{17}$}

a. Pemeliharaan anak yang belum mumayyiz atau belum berumur 12 tahun adalah hak ibunya;

b. Pemeliharaan anak yang sudah mumayyiz diserahkan kepada anak untuk memilih di antara ayah atau ibunya sebagai pemegang hak pemeliharaannya;

c. Biaya pemeliharaan ditanggung oleh ayahnya.

Kompilasi Hukum Islam kaitannya dengan masalah ini dibagi menjadi dua periode bagi anak yang perlu dikemukakan yaitu:

Periode Sebelum Mumayyiz, apabila terjadi perceraian di mana telah diperoleh keturunan dalam perkawinan itu dan pada masa tersebut seorang anak belum lagi mumayyiz atau belum bisa membedakan antara yang bermanfaat dan yang berbahaya bagi dirinya, maka anak tersebut dikatakan belum mumayyiz. KHI menyebutkan pada bab 14 masalah pemeliharaan anak Pasal 98 menjelaskan bahwa "Batas usia anak dalam pengawasan orang tuanya adalah sampai usia anak 21 tahun selama belum melakukan pernikahan". Pada Pasal 105 huruf (a) bahwa pemeliharaan anak yang belum mumayyiz atau belum berumur 12 tahun adalah hak ibunya. Kemudian KHI lebih memperjelas lagi dalam Pasal 156, dirumuskan sebagai berikut:

Akibat putusnya perkawinan karena perceraian adalah:

17 Pasal 105, KHI 
a. Anak yang belum mumayyiz berhak mendapatkan hadhanah dari ibunya, kecuali bila ibunya telah meninggal dunia, maka kedudukanya digantikan oleh:

1. Wanita-wanita garis lurus keatas dari ibu;

2. Ayah;

3. Wanita-wanita garis lurus keatas dari ayah;

4. Saudara perempuan dari anak yang bersangkutan;

5. Wanita-wanita kerabat menurut garis ke samping dari ibu;

6. Wanita-wanita kerabat menurut garis ke samping dari ayah;

7. Anak yang sudah mumayyiz berhak memilih untuk mendapatkan hadhanah dari ayah atau dari ibunya;

8. Apabila pemegang hadhanah ternyata tidak dapat menjamin keselamatan jasmani dan rohani anak, meskipun biaya nafkah dan hadhanah telah dicukupi, maka atas permintaan kerabat yang bersangkutan Pengadilan Agama dapat memindahkan hak hadhanah kepada kerabat lain yang mempunyai hak hadhanah juga;

9. Semua biaya hadhanah dan nafkah anak menjadi tanggung jawab ayah menurut kemampuanya, sekurang-kurangnya sampai anak tersebut dewasa dapat mengurusi diri sendiri sampai 21 tahun;

10. Bilamana terjadi perselisihan mengenai hadhanah dan nafkah anak, Pengadilan Agama yang memberikan putusan yaitu berdasarkan huruf (a), (b), (c), dan (d);

11. Pengadilan dapat pula dengan mengingatkan kemampuan ayahnya menetapkan jumlah biaya untuk pemeliharaan dan pendidikan anak-anak yang turut padanya. ${ }^{18}$

Periode Mumayyiz, pada masa ini seorang anak secara sederhana telah mampu membedakan mana yang berbahaya dan mana yang bermanfaat bagi dirinya. Oleh sebab itu, ia sudah dianggap dapat menjatuhkan pihaknya sendiri apakah ikut ibunya atau ikut ayahnya. Dengan demikian ia diberi hak pilih menentukan sikapnya. Hal ini telah diatur dalam KHI Pasal 105 ayat (b) bahwa: "Pemeliharaan anak yang sudah mumayyiz diserahkan kepada anak untuk memilih di antara ayah atau ibunya sebagai pemegang hak pemeliharaanya", dan juga terdapat dalam Pasal

18 Abdurrahman, Kompilasi Hukum Islam, (Jakarta: Akademika Pressindo, 2007), hlm. 151. 
156 ayat (b) yang menyebutkan bahwa anak diberi pilihan untuk ikut dalam asuhan ibu atau ayahnya.

Berakhirnya masa asuhan adalah pada waktu anak itu sudah bisa ditanya kepada siapa dia akan terus ikut. Batas usia anak dalam pengawasan orang tuanya adalah sampai usia anak 21 tahun selama belum melakukan pernikahan (Pasal $98 \mathrm{KHI}$ ). Jika anak tersebut memilih ibunya maka si ibu tetap berhak mengasuh anak itu. Jika anak itu memilih ikut ayahnya maka hak pengasuh pindah pada ayah.

\section{Pasal 98 KHI $^{19}$}

1) Batas usia anak yang mampu berdiri sendiri atau dewasa adalah 21 tahun, sepanjang anak tersebut tidak bercacat fisik maupun mental atau belum pernah melangsungkan pernikahan.

2) Orang tuanya mewakili anak tersebut mengenai segala perbuatan hukum di dalam dan di luar Pengadilan.

3) Pengadilan agama dapat menunjuk salah seorang kerabat terdekat yang mampu menunaikan kewajiban tersebut apabila kedua orang tuanya tidak mampu.

\section{Undang-Undang Nomor 23 Tahun 2002 Tentang Perlindungan Anak}

Kewajiban dan tanggung jawab orang tua diatur dalam Pasal 26 ayat (1) dan (2) Undang-Undang Nomor 23 Tahun 2002 Tentang Perlindungan Anak Pasal 26 yang berbunyi:

Pasal 26

1) Orang tua berkewajiban dan bertanggung jawab untuk:

a. Mengasuh, memelihara, mendidik dan melindungi anak;

b. Menumbuhkan anak sesuai dengan kemampuan, bakat dan minatnya;

c. Dan mencegah terjadinya pernikahan pada usia anak.

2) Dalam hal orang tua tidak ada atau karena suatu kewajiban dan tanggung jawabnya maka kewajiban dan tanggung jawab sebagaimana dimaksud dalam ayat (1) dapat beralih kepada keluarga, yang dilaksanakan sesuai dengan ketentuan perundang-undangan yang berlaku.

Didalam penjelasan Undang-undang Nomor 23 Tahun 2002 Tentang Perlindungan Anak ditegaskan: "Bahwa pertanggungjawaban orang tua, keluarga, masyarakat, pemerintah dan negara merupakan rangkaian kegiatan yang dilaksanakan secara terus-menerus demi terlindungnya

${ }_{19}$ Pasal 98, KHI 
dan terarah guna menjamin pertumbuhan dan perkembangan anak baik fisik mental, spiritual, maupun sosial".

\section{Maslahah Mursalah}

Yaitu menetapkan hukum dalam hal-hal yang sama sekali tidak disebutkan dalam Al-Qur'an maupun Hadits, dengan pertimbangan untuk kemaslahatan atau kepentingan hidup manusia yang berlandaskan pada asas menarik manfaat dan menghindari kerusakan. ${ }^{20}$ Yang menjadi tolok ukur suatu maslahah adalah terwujudnya tujuan syara"e atau lebih dikenal dengan istilah Maqhasid Syarieeah. Hal ini erat kaitannya dengan keselamatan dan kesejahteraan ukhrawi dan duniawi tidak akan mungkin dicapai tanpa terwujudnya tujuan syara ${ }^{\text {ee }}$ tersebut yang meliputi pemeliharaan lima hal yaitu: pemeliharaan agama, jiwa, akal, keturunan, dan harta. Lima hal ini disusun berurut berdasarkan prioritas urgensinya.

Maslahah mursalah sebagai metode istinbath hukum yang mempertimbangkan adanya kemanfaatan yang mempunyai akses secara umum dan kepentingan secara terbatas, tidak terikat. Dengan kata lain maslahah mursalah merupakan kepentingan yang diputuskan bebas namun tetap terikat pada konsep syari'ah yang mendasar. Karena syari'ah sendiri ditunjuk untuk memberikan kemanfaatan kepada umat dan berfungsi untuk memberikan kemanfaatan dan mencegah kemadzaratan (kerusakan).

Adapun untuk menjaga kemurnian metode maslahah mursalah sebagai landasan hukum Islam, maka harus mempunyai dua dimensi penting, yaitu sisi pertama harus tunduk dan sesuai dengan apa yang terkandung dalam nash (Al-Qur'an dan Hadist) baik secara tekstual maupun kontektual. Sisi kedua harus mempertimbangkan kepentingan manusia secara berkembang sesuai zamannya. Kedua sisi ini harus menjadi pertimbangan yang secara cermat dalam pembentukan hukum islam, karena bila kedua sisi diatas tidak berlaku secara seimbang, maka dalam istinbath hukumnya hanya akan menjadi sangat kaku dan di satu sisi lain terlalu mengikuti hawa nafsu.

\section{Penguasaan Hak Asuh Anak Di Bawah Umur Kepada Bapak}

Didalam konsep KHI, jika terjadi perceraian, pemeliharaan anak yang belum mumayyiz (belum 12 tahun) adalah hak ibunya, setelah mumayyiz diserahkan pada anak untuk memilih ayah atau ibunya sebagai pemegang

${ }^{20}$ Amin Farih, Kemaslahatan dan Pembaharuan Hukum Islam Abu Ishaq Ibrahim alSyathibi, hlm. 16-17 
hak pemeliharaannya. Sedangkan biaya pemeliharaan tetap ditanggung oleh ayahnya. Semua biaya hadhanah dan nafkah anak tetap merupakan kewajiban ayah sesuai kemampuannya terhadap anak-anaknya yang belum berusia 21 tahun. Namun pasal ini bukan berarti meniadakan atau menghapus hak bapak untuk mengasuh anak kandungnya pasca perceraian dengan istrinya.

Dalam contoh putusan perkara nomor 0830/Pdt.G/2019/PA.Dmk, majelis hakim memberikan hak asuh anak dibawah umur kepada bapak pasca perceraian. Dengan pertimbangan, ibu dinilai tidak memenuhi syarat untuk diberikan hak hadhanah karena kondisi psikis atau kejiwaan terganggu, mengalami depresi. Pertimbangan hukum yang dilihat dari faktor psikis, kedekatan antara anak dan bapak ketika gangguan kejiwaan yang dialami ibu sedang kambuh dan membutuhkan perawatan khusus.

Meskipun sebenarnya perlu ditekankan bahwa ibu memiliki kelembutan sehingga dapat memberikan kasih sayang dan perhatian yang lebih terhadap anaknya khususnya yang masih dibawah umur, karena pertimbangan kemaslahatan tumbuh kembangnya anak yang lebih baik untuk kedepannya atau secara istilah disebut the best interest of child. Hal ini juga tentu mengesampingkan Pasal 156 Kompilasi Hukum Islam butir (c) disebutkan bahwa bapak menjadi pengasuh dari anaknya apabila si ibu telah meninggal dunia, sedangkan perempuan-perempuan dalam garis lurus ke atas ibu sudah tidak ada lagi.

Pasal ini dapat menjadi acuan bahwa bapak juga mempunyai hak dalam pengasuhan dan pemeliharaan anaknya meskipun hak tersebut sangatlah jauh dibandingkan dengan hak ibu, sesuai konteks kepentingan terbaik untuk anak. Dapat ditarik kesimpulan dalam permasalahan ini bahwa, penguasaan metode penerapan hukum oleh hakim dalam menjalankan tugas kekuasaan kehakiman berdasarkan mazhab historis dan aliran Freirechtbewegung, karena undang-undang dianggap tidak lengkap, hakim diharapkan dapat menyesuaikan undang- undang dengan keadaan, hakim tidak semata-mata mengabdi kepada kepastian hukum, melainkan juga haruas merealisasikan keadilan.

Dalam aspek kehidupan manusia, terminologi pemreliharaan anak perlu dipahami secara luas dan menyeluruh. Ini dimaksudkan, agar orang tua tidak hanya memprioritaskan kewajibannya pada terpenuhinya kebutuhan matriil si anak, tetapi lebih dari itu kebutuhan mereka akan kasih sayang, pendidikan, kesehatan, dan lain-lain turut menjadi faktor 
penentu pembentukan kepribadian anak. Kualitas komunikasi antara anak dan orang tuanya mutlak perlu mendapatkan perhatian.

Setiap orang yang memiliki hak hadhanah hendaknya memiliki rasa kasih sayang, kesabaran, dan mempunyai keinginan agar anak itu baik (saleh/salehah) di kemudian hari. Selain itu harus mempunyai waktu yang cukup pula untuk melaksanakan tugas itu. Pengasuhan anak oleh bapak didalam hukum positif sebagaimana tertuang dalam KHI Pasal 105 merupakan pilihan kedua bagi majelis hakim setelah ibu dinilai tidak sanggup atau kurang baik untuk diberikan hak asuh anak karena pertimbangan kemaslahatan tumbuh kembang anak lebih baik untuk kedepannya.

Kompilasi Hukum Islam tidak mengatur mengenai pencabutan hak hadhanah si ibu, namun dalam hal ini dapat dipakai peraturan mengenai pencopotan hak perwalian. Hal ini digunakan karena Kitab UndangUndang Hukum Perdata di Indonesia hak asuh, hak mendidik, mengasuh dan lain sebagainya masuk dalam kategori hak perwalian. Seseorang dapat ditarik, diangkat, dicopot dari statusnya sebagai wali apabila mempunyai sifat-sifat tertentu, dalam pasal 109 Kompilasi Hukum Islam disebutkan bahwa Pengadilan agama atau badan hukum tertentu dapat mencabut perwalian seseorang atau badan hukum dan memindahkannya kepada pihak lain atas permohonan kerabatnya bila wali tersebut pemabuk, penjudi, pemboros, gila dan atau melalaikan atau menyalahgunakan hak dan wewenangnya sebagai wali demi kepentingan orang yang berada dalam perwaliannya.

Kekuasaan orang tua dapat dicabut atau dialihkan apabila alasanalasan yang menuntut pengalihan tersebut, sebagaimana dinyatakan dalam pasal 49 Undang-Undang Nomor 1 tahun 1974 tentang Perkawinan ${ }^{21}$ :

1) Salah seorang atau kedua orang tua dapat dicabut kekuasaan terhadap seorang anak atau lebih untuk waktu yang tertentu atas permintaan orang tua lain, keluarga anak dalam garis lurus keatas atau saudara kandung yang telah dewasa atau pejabat yang berwenang, dengan putusan pengadilan dalam hal :

a. Ia melalaikan kewajibannya terhadap anaknya.

b. Ia berkelakuan buruk sekali.

${ }^{21}$ Ahmad Rofiq, Hukum Perdata Islam di Indonesia, (Jakarta: Rajawali Pers,2013), hlm. 202. 
2) Meskipun orang tua dicabut kekuasaannya, mereka masih tetap berkewajiban untuk memberi biaya pemeliharaan kepada anak tersebut.

Lebih lanjut apabila Pasal di atas dihubungkan dengan Pasal 1 Undang-Undang Nomor 23 Tahun 2002 terdapat relevansi karena perilaku buruk ibu sebahai pemegang hak hadhanah sangat bertentangan dengan tujuan hadhanah yaitu untuk menjaga keselamatan hidup seorang anak, sebab perilaku buruk ibu yang menderita depresi ringan yang dapat mengakibatkan kekerasan terhadap anak akan menimbulkan dampak buruk terhadap anak tersebut baik fisik maupun psikis. Pada dasarnya orang tua memiliki tanggung jawab melindungi, mengasuh, dan mendidik anak sehingga menjadi bekal kehidupannya di masa depan. Hal ini ditegaskan dalam Pasal 1 Undang-Undang Nomor 23 Tahun 2002.

"Bahwa pada dasarnya Perlindungan anak adalah segala kegiatan untruk menjamin dan melindungi anak dan hak-haknya agar dapat hidup, tumbuh, berkembang, dan berpartisipasi, secara optimal sesuai dengan harkat dan martabat kemanusiaan, serta mendapat perlindungan dari kekerasan dan diskriminasi. 22

Kemudian Pasal 14 Undang-Undang No.23 Tahun 2002 tentang Perlindungan Anak sebagaimana diubah dengan Undang-Undang Nomor 35 Tahun 2014 yang menjelaskan, setiap anak berhak diasuh oleh orang tuanya sendiri, kecuali jika ada alasan dan atau aturan hukum yang sah menunjukkan bahwa pemisahan itu adalah demi kepentingan terbaik bagi anak dan merupakan pertimbangan terakhir. Namun demikian, setiap anak berhak atas :

a. Bertemu langsung dan berhubungan pribadi secara tetap dengan kedua orang tuanya;

b. Mendapat pengasuhan, pemeliharaan, pendidikan dan perlindungan untuk proses tumbuh kembang dari kedua orang tuanya sesuai dengan kemampuan, bakat, dan minatnya;

c. Memperoleh pembiayaan hidup dari kedua orang tuanya dan memperoleh hak anak lainnya.

\section{Penutup}

Pasal 105 Kompilasi Hukum Islam dijelaskan bahwa hak asuh anak yang masih berusia dibawah 12 tahun adalah hak ibunya, ada beberapa peraturan perundang-undangan di Indonesia yang dapat dijadikan acuan

22 Undang-undang No. 23 Tahun 2002 
agar hak asuh anak di bawah umur tersebut dapat dikuasakan kepada bapak kandungnya, diantaranya:

1. Pasal 41 Undang-Undang Nomor 1 Tahun 1974 tentang Perkawinan,mengenai persamaan hak antara ibu dan bapak terkait hak asuh anak dengan mengedepankan kepentingan anak tersebut.

2. Pasal 49 Undang-Undang Perkawinan mengenai permintaan pencabutan hak asuh anak oleh salah satu ataupun kedua orang tua maupun keluarga dari anak tersebut.

3. Pasal 14 Undang-Undang Perlindungan Anak mengenai pemisahan seorang anak dengan salah satu atau kedua orang tua demi

Kepentingan terbaik bagi anak dan merupakan pertimbangan mutakhir dengan tidak menghilangkan hak-hak seorang anak yang harus dipenuhi orang tua. Hukum islam pun memberikan kelonggaran jika ibu mengalami depresi yang merupakan udzur syar'i tidak terpenuhinya persyaratan menjadi hadhin. Secara maslahah mursalah sesuai dengan Kaidah fiqih "Jika ada dua mudarat yang saling bertentangan maka ambil yang paling ringan". Jika anak dikuasakan kepada ibu yang mengalami depresi, hal yang dikhawatirkan jika mendatangkan mudarat (bahaya). Bapak dianggap sebagai sandaran ternyaman untuk anak sebagai pengganti kedudukan ibu untuk kepentingan pertumbuhan, pendidikan dan kenyamanan anak, semuanya itu untuk perlindungan dan kemaslahatan anak atau the best interest of child.

\section{Daftar Pustaka}

Undang-Undang Nomor 1 tahun 1974 Tentang Perkawinan Undang-undang No. 23 Tahun 2002 Tentang Perlindungan Anak Kompilasi Hukum Islam

Al-Hamdani. Risalah Nikah: Hukum Perkawinan Islam. Jakarta: Pustaka Amani. 2002.

Abdul Rahman Ghazaly. Fikih Munakahat. Jakarta: Kencana. 2006.

Ahmad Rofiq. Hukum Perdata Islam di Indonesia. Jakarta: Rajawali Pers. 2013.

Aminuddin \& Slamet Abidin. Fikih Munakahat 2, Bandung: Cv. Pustaka Setia. 1999.

Amin Farih. Kemaslahatan dan Pembaharuan Hukum Islam Abu Ishaq Ibrahim al- Syatibi. Semarang: Walisongo Press. 2008.

Satria dan M. Zeim Effend. Problematika Hukum Keluarga Islam Hukum Keluarga Islam Kontemporer. Jakarta: Kencana. 2004. 
Syamsu Andi dan Fauzan Alam. Hukum Pengangkatan Anak Prespektif Islam. Jakarta:Kencana. 2008.

Zainudin Ali. Hukum Perdata Islam di Indonesia. Jakarta: Sinar Grafindo. 2016.

Zakiah Darajat. Ilmu Figh, Yogyakarta: Dana Bakti Wakaf. 1995.

Adil, Legalitas Penguasaan Hak Asuh Anak, ADIL: Jurnal Hukum Vol.10 No 1.

Ali Imron, 2016, Memahami Konsep Perceraian Dalam Hukum Keluarga, Buana Gender-Vol. I Nomor I, Januari - Juni.

Anshory, Mohammad, 2010, "Hak hadhanah terhadap ibu wanita karir (analisa putusan perkara nomor: 458/Pdt.G/2006/PA.Dpk Pengadilan Agama Depok)", Skripsi : UIN Syarif Hidayatullah Jakarta. 